\title{
Mind the gap: Post earthquake community wellbeing?
}

\author{
Nicky Cooper-Cabell
}

Nicky Cooper-Cabell is a recent graduate of the Bachelor of Social Work programme at the Christchurch Polytechnic and Institute of Technology (CPIT), having completed her degree in-between the Canterbury earthquakes. Nicky worked at Nga Maata Waka as part of the Earthquake Co-ordination team following the September and February earthquakes and is now working at CYF as a Care and Protection Social Worker.

\section{Abstract}

Following the September 2010 and February 2011 Canterbury earthquakes the Stronger Canterbury Strategic Planning Framework was developed by the National Psychosocial Response Subgroup with support from the Psychosocial Recovery Advisory Group under the auspices of the Ministry of Health in conjunction with the National Health Emergency Plan (Ministry of Health, 2007, p.18). The Framework's purpose was to provide an overarching context for the Christchurch Psychosocial Response Subgroup as well as applicable Community Wellbeing subgroups to assist in planning the psychosocial recovery in response to the Canterbury earthquakes. Within the document two essential components to the psychosocial recovery for Canterbury are identified: individual recovery and wellbeing, and the building of community resilience while supporting psychosocial wellbeing. Implicit in the document is the notion that provided the right supports are in place, recovery will occur. This article argues the current pervasive neo-liberal perspective has hampered the ability of those supports to be fully realised. To begin, the strategic planning aims of addressing individual psychosocial wellbeing and community resilience will be defined in this review. Secondly, examples illustrating how the pervading neo-liberal perspective has contributed to the failure of the policy to assist community recovery will be discussed. Examples referring to the notions of rights, equality, social justice and the Treaty of Waitangi will be provided. To conclude, the slow pace of the recovery for Cantabrians has had, and continues to have, multiple implications for the social work community. It is over two years on from the first earthquake, and much of the population are still struggling to gain equilibrium. Social workers in Canterbury have been working tirelessly to improve outcomes for clients. It is suggested it is time social work as a national body advocates for the stakeholders to pay more attention to the original intent of the framework.

\section{Introduction}

The Canterbury region was struck by an earthquake measuring 7.1 on the Richter scale at $4.35 \mathrm{am}$ on the 4 th of September 2010. There were no direct fatalities but there was widespread damage to public and private buildings (New Zealand Government (NZG), 2011, p. 19). On the 22nd of February 2011 another large earthquake centred south east of Christchurch struck at $12.52 \mathrm{pm}$. This earthquake measured 6.2 on the Richter scale and its timing mid-week and in the middle of the day could not have been worse (NZG, 
2011, p. 19). This second earthquake left 181 people dead and over 2,000 people injured (Family \& Community Services, 2011, para. 2). The subsequent failure of the city's infrastructure (power and water supplies) combined with the collapse of many public and private dwellings led to a state of emergency being declared (NZG, 2011, p. 19). The Christchurch earthquakes were a natural disaster, although Bragin (2011, p. 365) suggests natural disasters are anything but natural; rather they are dependent on the quality of the infrastructure used to manage them. Many in Christchurch are questioning the integrity of the infrastructure being used to manage the recovery. Disasters can cause disruption in almost every aspect of everyday life 'not only loved ones killed but also the loss of home, possessions, community and social fabric, historic continuity and plans for the future' (Bragin, 2011, p. 375).

To respond to the devastation following the first earthquake a dedicated centralised agency, the Canterbury Earthquake Recovery Authority (CERA) was established. CERA was established under the auspices of the State Sector Act 1988 (CERA, 2011, p. 3). Following the second earthquake, a new Act of Parliament, the CERA Act 18th April 2011, was instigated, providing the Chief Executive of CERA and the Earthquake Minister with additional powers (CERA, 2011, p. 4). The additional powers enable both the Minister and CERA to implement measures to aid the recovery as they see fit. CERA functions in partnership with the Christchurch and Waimakariri local and regional councils, central government bodies, Te Runanga O Ngai Tahu (the local iwi), the voluntary sector and local community and business groups (CERA, 2011, p. 3).

CERA's role is to restore services and economic, social, community and cultural wellbeing to greater Christchurch (CERA, 2011, p. 3). The Stronger Canterbury Strategic Planning Framework (SCSPF) was developed by CERA and its partners in May 2011 (NZG, 2011, p. 3). This framework was intended as an 'over-arching contextual guide for those responsible in planning and assisting the psychosocial response to the Canterbury earthquakes' (NZG, 2011, p. 3).

The inclusion of Te Runanga O Ngai Tahu reflects the Treaty of Waitangi principles of partnership, protection and participation as defined by the Waitangi Tribunal under the auspices of the Treaty of Waitangi Act 1975 (Waitangi Tribunal, 2012, para. 3). Participation is evidenced by the inclusion of Te Puni Kokiri and Ngai Tahu in informing the framework (SCSPF, 2011, p. 34). Te Runanga O Ngai Tahu (local iwi, ruling body) is an active partner in the recovery partnership with CERA (CERA, 2011, p. 3). He Huanui Ara Ake mo Waitaha, a Pathway to Recovery for Canterbury, is the title of the Ngai Tahu recovery strategy produced alongside and in partnership with the SCPSCF (Te Runanga O Ngai Tahu (TRONT), 2011, p. 1). Interestingly while Ngai Tahu acknowledges their important statutory status as a partner to the recovery strategy, they also clearly assert their preliminary tribal position and their tribal priorities for the draft CERA recovery strategy (TRONT, 2011, p. 11). Acknowledged in the framework is the importance of supporting wellbeing in communities for all members (SCSPF, 2011, p. 34). It is recognised that not all groups, such as those where people have pre-existing conditions like diabetes and asthma, are able to access key resources and may therefore have lower levels of wellbeing (SCSPF, 2011, p. 34). Maori are listed in the SCSPF as being over represented 'in most of the vulnerable groups' (SCSPF, 2011, p. 34). In recognising Maori as possibly more at risk due to pre-existing conditions the principle of protection is recognised. 


\section{Psychosocial wellbeing and community resilience}

Psychosocial refers to the combination of a person's innermost thoughts and feelings and the social context in which they exist (Bragin, 2011, p. 374). Psychosocial wellbeing 'is a state in which one is able to master the life tasks of love and work, family and community, and ascribe meaning to daily life' (Bragin, 2011, p. 374). Psychosocial support is the process of supporting resilience by taking actions to address needs both psychological and contextual (infrastructure) to enable individual and community recovery (The International Reference Centre for Psychosocial Support, 2009, p. 21). The SCSPF utilises the Inter Agency Standing Committees (IASC) intervention pyramid for mental health and psychosocial support in emergencies as a guide to the level of psychosocial supports needed.

The base of the pyramid is represented by the provision of basic services and security for all as the first response resonating with Maslow's Hierarchy of Needs. Secondly, the pyramid identifies community and family supports to be provided for a smaller number of people who are able to maintain psychosocial wellbeing if the right supports are in place. Thirdly, more focused non-specialised supports for a smaller number of people who require slightly more specialised help. The tip of the pyramid represents specialised services for those requiring additional support for needs not being met by the above layers (IASC, 2007, p. 13). Alongside psychosocial wellbeing the framework also states the importance of community resilience.

Community resilience is described as the ability of the community to adapt and function effectively following a disaster (Norris, Stevens, Pfefferbaum, Wyche \& Pfefferbaum, 2007, p. 127). Norris et al. (2007, p. 127) suggest that in order for communities to build resilience, both risk and resource inequities must be reduced, local people must be involved in decision making and flexibility is important. The SCSPF, in line with current disaster response literature, implies that in time and with the right supports and community engagement, recovery will occur for nearly all of the affected Canterbury population. The policy intent with its collectivist humanistic tenet to guide the recovery could be viewed as very socialist in its promise (Dean, 2008 , p. 84). A socialist perspective maintains social problems such as an earthquake require collective solutions; this is reflected in the SCSPF's commitment to building community resilience (Duncan, 2004, p. 88). However, one could argue a decidedly neo-liberal perspective in the execution of the policy has led to the failure of the policy to fulfil its original intent.

\section{Community wellbeing?}

A neo-liberalist perspective maintains the welfare state should cut back on providing welfare to save government spending and allow greater choice through market provision (Ellison, 2004, p. 61). Neo-liberal policies seek 'to govern by means of the free market, or by means that emulate free market transactions' (Duncan, 2004, p. 184). In some instances, homes which were deemed irreparable by private insurers have now been deemed repairable due to new Government guidelines (IAG, 2012, p. 3). The change of Government guidelines will save insurance companies hundreds of thousands of dollars, thereby reflecting a typically neo-liberal response.

The aims of social policy include improving the level and the distribution of wellbeing (Geiringer \& Palmer, 2007, p. 14). The New Zealand Government, by being a signatory to 
international law, is bound to take a rights approach to social policy (Geiringer \& Palmer, 2007, p. 14). Therefore all New Zealand social policy must reflect a rights-based approach. The SCSPF ensures the provision of a rights-based approach by highlighting the need to keep individuals and communities informed to mitigate stress, 'those whose homes have significant damage are kept informed regarding the process for getting them repaired' (SCSPF, 2011, p. 34). The SCSPF also states that the process of decision making should be timely, with no unnecessary delays (SCSPF, 2011, p. 34). Unfortunately, for those 10,000 homeowners who are still waiting to know two years on whether their homes can be repaired or need to be demolished, the lack of information has been extremely stressful (Canterbury Earthquake Commission (CEQC), 2012, para. 3). The right of homeowners to be informed in a timely manner regarding significant damage to their homes has been superseded by the protection the Government has given private insurance companies.

Both rights and equality imperatives require the altering of conditions that further create poverty and marginalisation for those affected (Braveman \& Gruskin, 2003, p. 540). The SCSPF reflects this notion in aiming to support those whose homes have suffered damage to have 'safe, secure and healthy living arrangements' (SCSPF, 2011, p. 34). The housing market in Christchurch has been significantly depleted post the earthquakes. Rental accommodation prices have risen and rental listings have fallen (Hoyle, 2012, para.11). As the Christchurch rebuild gains momentum the situation is expected to worsen, with large numbers of overseas workers expected to participate in the rebuild (Hoyle, 2012, para. 11).

Rising rents and the shortage of properties has already forced people to live in badly damaged homes, garages and even in cars. Labour Member of Parliament Rino Tirikatene cited examples to the Housing Minister in March 2012, 'for example, 11 people crowded into a two bedroom house, people renting a garage to live in for NZ\$160 a week, or the young man sleeping in his car when he's not delivering pizzas, because he can't afford a rental or find a place to live' (Interest, 2012, Para. 17). The Earthquake Recovery Minister declared the rental housing crisis is best left to the market ('Christchurch rent crisis', 2012). When questioned in Parliament over the wisdom in leaving the market to decide, the Minister stated that the new opportunities resulting from the Government purchasing red-zoned properties (deemed by the Government as being uneconomic to repair) will suffice (Parliament, 2012, p. 10). In choosing not to intervene in a timely fashion, the market (private landlords) has been privileged over the unhoused.

The notion of a select few benefitting from disaster is not a new one, 'After years spent visiting other disaster zones, from post-tsunami Sri Lanka to post-Katrina New Orleans, I've come to think of these Green Zone/Red Zone worlds as something else: Fast forward versions of what 'free market forces are doing in our societies even in the absence of war' (Klein, 2007, p. 48). Haigh and Sutton (2012, p. 270) suggest the motivation of many construction companies, in engaging in post-disaster reconstruction, is based on the premise that there are profits to be made.

In 2006 research seeking to understand New Zealanders' concept of social justice found 'social justice would principally be concerned with equality, tolerance, compassion, fairness and participation' (Friesen, 2006, p. 158). Social justice is also concerned with who gets entitlements from the Government and how that welfare should be paid for (Duncan, 2004, p. 82). Neoliberals argue welfare should primarily be provided by relatives or voluntary 
groups; the state is viewed as providing residual-only contributions, as a last resort (Cheyne, O’Brien, \& Belgrave, 2005, p. 82). By November 2012, earthquake-fuelled inflation (disaster capitalism?) saw the price of purchasing an average home in Christchurch rise to $\$ 400,000$, an increase of $13 \%$, which is in stark contrast to the national increase of $4 \%$ (McDonald, 2012, para. 3). Welfare agencies have campaigned long and hard for affordable social housing following the Canterbury earthquakes. Finally in November 2012, for the first time ever in New Zealand in response to the housing shortage, the Government announced 'Housing New Zealand to link with a private developer to build a mixture of social housing and affordable homes for sale on five Christchurch sites'. Welfare agencies have welcomed the news (Gates, 2012, para. 4).

The SCSPF states that those guiding the recovery should take action to address gaps in the social or physical infrastructure needed for community action (SCSPF, 2011, p. 34). Yet the response given by the Prime Minister to the question over what help the 10,000 uninsured Cantabrians might receive was, 'it is going to be a distressing experience' (Grant, 2010, para. 8). The Earthquake Minister, when queried on what help the uninsured may receive, replied 'the priority is to help those who were insured and have helped themselves' ('Crown to buy' 2012, para. 18). The response given to the uninsured was typically neo-liberal; the assistance provided to the uninsured will be reluctant and only when all other avenues are exhausted. Those on lower incomes or benefits may not have been able to afford the cost of insurance (McClure \& Williams, 1996, p. 237). Finally, in September 2012, the Earthquake Minister announced the owners of uninsured land will receive $50 \%$ of the latest rateable value of their land and nothing for the house itself. If owners decide to settle with the Crown, both the land and any remaining buildings will then become the property of the Crown from the settlement date (CERA, 2012, p. 1).

\section{Social workers and social change}

Hutton (2001, p. 6) writes of the competing community needs post disaster, in this context:

...community level decisions are influenced by more powerful stakeholders and often come at the expense of alternative priorities which might serve more vulnerable or marginalized sections of society.

The author also suggests that the broader psychological aspects of disasters such as the political structures underpinning recovery responses must be examined (Hutton, 2001, p. 6). Clearly, in Canterbury the decisions made so far seem to be privileging the market over meeting the needs of the more vulnerable. To foster community resilience, planning and decision making needs to include all members of a society, not just the major stakeholders (Hutton, 2001, p. 6). Mathbor (2007, p. 366) posits that social workers know their community and are therefore ideally placed to address disaster recovery at every level. Included in the Aotearoa New Zealand Association of Social Workers Code of Ethics for social workers in New Zealand is the ethos 'the social work profession promotes social change, problem solving in human relationships and the empowerment and liberation of people to enhance wellbeing' (Aotearoa New Zealand Association of Social Workers, 2008 , p. 6). Social workers have been trained to understand the integrated nature of social connections and are therefore ideally placed to support resilience (Bragin, 2011, p. 384). Social workers learn how to take into account structural issues of power and discrimination 
when assessing a situation. As members of this profession they are skilled at recognising oppression (Bragin, 2011, p. 384).

Historically, social work originates from grassroots movements that have 'continuously dealt with shocks and utilized people's strengths' (Mathbor, 2007, p. 366). Psychosocial support to facilitate individual and community wellbeing has been long recognised by the social work community as essential (Mathbor, 2007, p. 366). However, Pyles (2008, p. 331) suggests social work intervention is not proactive enough post disaster. Perhaps as a national body it is time social workers New Zealand-wide advocate for more attention to be paid to the original intent of the SCSPF? Allen (1993, as cited in Soliman \& Rogge, 2002, p. 17) argues social work accountability in disaster recovery '...lies in the responsibility to advocate and to open space for client voices in the developing conversation, so that they can define themselves, their problems, their preferred solutions'.

Two years since the first earthquake and 18 months since the SCSPF was written, psychosocial wellbeing and community resilience remains elusive for many in Canterbury. Some 414,599 claims requiring earthquake repairs to buildings have been made to the CEQC, of which in November 2012, 26,280 had been completed (CEQC, 2012, para 1). Social workers and community organisations in Canterbury have been working tirelessly in this environment for over two years now. In February 2012, 41 Christchurch community groups were publicly recognised at an awards ceremony for contributing extraordinary leadership and responsiveness following the Canterbury earthquakes (Community Response, para. 4). One of those groups recognised, Te Whare Roimata, commented that as time has passed those needs have changed and now they are spending time working on submissions to meet those needs (Family \& Community Services, 2011).

The Operations Manager for Relationship Aotearoa, J. Martin, noted that the number of tired, stressed residents and practitioners had increased (personal communication, March 12, 2012). The Chief Executive of Stopping Violence Services in Canterbury has observed that a delayed reaction to the earthquakes is beginning to occur as anxiety and depression develop (Stewart, 2012, para. 9). Failed businesses, the stress of living with relatives and strained relationships due to the after effects of the earthquakes are being held responsible (Stewart, 2012, para. 7). Ongoing challenges such as the Education Renewal Recovery Programme, which proposes sweeping changes to education provision, provide further stressors to an already stressed community (Ministry of Health, 2012).

\section{Conclusion}

The SCSPF could be an effective document for the recovery if the recovery authorities and their partners follow the guidelines and applied its original intent. The Canterbury and Christchurch earthquakes necessitated the need for a dedicated, centralised recovery authority to be established. Social policy in the form of the SCSPF was then developed as an overarching guide to aid the recovery partners to restore psychosocial wellbeing and the building of community resilience. This article has argued that a neo-liberal perspective has hindered the ability of the SCSPF's aims to reduce risk and inequities and to actively involve the whole community in the decision-making process. Two years after the first earthquake many homeowners are still awaiting information regarding the possible demolition of their homes. A shortage of rental accommodation and the accompanying higher rents are forc- 
ing those on low incomes to live in sub-standard conditions. The needs of more powerful stakeholders are being prioritised over those with little power. The SCSPF does reflect the principles of partnership, protection and participation according to the Treaty of Waitangi, while also noting Ngai Tahu's tribal priorities.

The slow pace of the recovery is having major implications for social workers trying to aid psychosocial recovery and the building of community resilience. Social work as a profession is ideally placed to aid disaster recovery for all sectors of society. Social workers and welfare agencies in Canterbury have been constantly advocating for change and this has led to changes in policy. Perhaps social workers in Canterbury need to enlist the support of the wider social work fraternity in New Zealand to advocate for the original intent of the SCSPF to be actioned. Following the original intent of the framework will not return loved ones but can help restore safe homes, possessions, community, social fabric and hope for the future.

\section{References}

Aotearoa New Zealand Association of Social Workers. (2008). Code of Ethics (2nd rev.). Christchurch, New Zealand: Author. Bragin, M. (2011). Clinical social work in situations of disaster and terror. In J.Brandell (Ed.,) Theory and practice in clinical social work. (2nd ed., pp 373-405).Thousand Oaks, CA: Sage Publications.

Braveman, D., \& Gruskin, S. (2003). Poverty, equity, human rights and health. Bulletin of the World Health Organisation, 81(7), 539-545. Retrieved from http: / / www.scielosp.org/pdf/bwho/v81n7/v81n7a13.pdf.

Canterbury Earthquake Commission. (2012). Scorecard. Retrieved Nov 13th 2012 from: http:/ / www.eqc.govt.nz / canterbury-earthquakes/progress-updates/scorecard.

Canterbury Earthquake Recovery Authority. (2011a) Statement of intent. 1 July 2011-30 June 2016. Retrieved from: http: / / cera.govt.nz/ sites / cera.live.egressive.com/files/common/ cera-soi-2011-2016.pdf.

Canterbury Earthquake Recovery Authority. (2011b). Briefing for the Minister. Retrieved April 14th 2012 from: http: / / cera.govt.nz / sites / cera.govt.nz / files / common / cera-briefing-for-the-incoming-minister-december-2011-20120202.pdf.

Canterbury Earthquake Recovery Authority. (2011c). Iwi recovery programme. Retrieved June 1st 2012 from Canterbury Earthquake Recovery Authority website: http: / / cera.govt.nz / recovery-strategy / leadership-and-integration/ iwi-maori-recovery-programme.

Canterbury Earthquake Recovery Authority. (2012). Crown offer to uninsured improved properties in the flat land residential red zones [Fact Sheet]. Retrieved from http:/ / cera.govt.nz/sites/cera.govt.nz/files/common/factsheet-crown-offer-to-uninsured-improved-properties-in-the-flat-land-residential-red-zones-20120913.pdf.

Cheyne, C., O’Brien, M., \& Belgrave, M. (2005). Social policy in Aotearoa New Zealand. A critical introduction (3rd ed.). Melbourne, Australia: Oxford University Press.

Christchurch rent crisis 'best left to market' (2012, March 3). The Press. Retrieved from http: / / www.stuff.co.nz.

Community Response. (n.d). Social sector recognised at Christchurch awards ceremony. Retreived February 18 th 2013 from Community Response Website: http:/ / www.communityresponse.org.nz/my-community/community-response-model / community-response-forums / canterbury-forum/ canterbury-forum-news-and-events / social-sector-awards-media-release.html.

Dean, H (2008). The socialist perspective. In P. Alcock., M. May., \& K. Rowlingson (Eds.), The students companion to social policy (3rd ed pp. 84-90). Oxford, England: Blackwell Publishing.

Duncan, G. (2004). Society and politics: New Zealand social policy (2nd ed.). Auckland, New Zealand: Pearson Education

Ellison, N. (2008). Neo-Liberalism. In P. Alcock., M. May., \& K. Rowlingson (Eds.), The students companion to social policy (3rd ed pp. 61-68). Oxford, England: Blackwell Publishing.

Family and Community Services. (2011). Canterbury social services earthquake. Retrieved April 14th 2012 from Family and Community Services Website: http:/ / www.familyservices.govt.nz/working-with-us/news-room/ newsletters / community-connect/ issue-11 / canterbury-social-services-earthquake.html.

Friesen, M. (2006). Social justice survey. Exploring social justice: A New Zealand perspective. Retrieved February 18th 2012 from Social Justice New Zealand Website: http: / / www.socialjustice.co.nz/social_justice_excerpt.pdf.

Gates, C. (October, 31). Housing NZ to build for private sale. The Press. Retrieved from http:/ / www.stuff.co.nz/ the-press / business / your-property / 7884484/Housing-NZ-to-build-for-private-sale.

Geiringer, C, \& Palmer, M. (2007). Human rights and social policy in New Zealand. Retrieved from http: / / www.msd. govt.nz/ documents / about-msd-and-our-work/publications-resources / journals-and-magazines/social-policy-journal/spj30/30-pages12-41.pdf.

Grant, J. (2010). Helping the over 10,000 uninsured quake victims will create a moral hazard. Retrieved April 142012 from Interest.co.nz website: http: / / www.interest.co.nz/insurance/50615/helping-over-10000-uninsuredquake-vic... 
Haigh, R., \& Sutton, R. (2012). Strategies for the effective engagement of multi-national construction enterprises in post disaster building and infrastructure projects. International Journal of Disaster Resilience in the Built Environment, 3(3), 270-282.

Hoyle, J. (2012). Stark realities for southern welfare centres. Retrieved May 9th from Salvation Army website: http: / / www.salvationarmy.org.nz/ research-media/ media-centre / local-news / stark-realities-for-southern-welfare-centres/.

How it works: payout case studies (2011, June 23). The Press. Retrieved from http: / / www.stuff.co.nz.

Hutton, D. (2001). Psychosocial aspects of disaster: Integrating communities into disaster planning and policy making. (Paper no 2). Retrieved from http: / / www.iclr.org/images/Psychosocial_aspects_of_disaster_recovery.pdf.

IAG. (2012). Factors affecting whether your home can be repaired or needs replacing. Retrieved May 9th 2012, from IAG website: http: / / www.iag.co.nz/News / Documents / IAG1340-1\%20IAG\%20Repair\%20or\%20Rebuild\%.

Inter Agency Standing Committees. (2007). Guidelines on mental health E psychosocial support in emergency settings. (Handbook) Geneva: Author.

International Federation of Social Work. (2005). Definition of social work. Retrieved April 14th 2012 from International Federation of Social Work website: http: / / www.ifsw.org/ f38000138.html.

Klein, N. (2007, September). Disaster capitalism. The new economy of catastrophe. Harpers, (9), 47-58.

Mathbor, G. (2007). Enhancement of community preparedness for natural disasters: The role of social work in building social capital for sustainable disaster relief and management. International Social Work, 50(3) $357-369$. doi: $10.1177 / 002087076049$.

McClure, J., \& Williams, S. (1996). Community preparedness: Countering helplessness and optimism. In D. Paton, \& N. Long (Eds.). Psychological aspects of disasters (pp. 237- 254). Palmerston North, New Zealand: The Dunmore Press.

MacDonald, L. (2012, November 9). Property prices through the roof. The Christchurch Press. Retrieved from http: / / www.stuff.co.nz / the-press / business / your-property / 7926241 / Property-prices-through-the-roof.

Ministry of Health. (2012) Future directions. The draft education renewal programme. (Brochure) Retrieved from http: / / shapingeducation.minedu.govt.nz/wp-content/ uploads/2012/05/FutureDirectionsSelfFacilitationPPT.pdf.

New Zealand Government. (2011). Stronger Canterbury earthquake recovery: Strategic planning framework. Retrieved from http: / / www.msd.govt.nz / about-msd-and-our-work/ publications-resources / planning-strategy / strategic-planning-framework/index.html.

Norris, F., Stevens, S., Pfefferbaum, B., Wyche, K., \& Pfefferbaum, R. (2007). Community resilience as a metaphor, theory, set of capacities and strategy for disaster readiness. American Journal of Community Psychology, 41, 127150. doi: 10.1007/s10464-007-9156-6.

Parliament. (2012). First session, fiftieth parliament. Parliamentary debates (unedited). Retrieved May 9th from http: / / www.parliament.nz/NR/rdonlyres / 4E13EDD4-8951-444A-B9E1-3E0BAF7C8500/212029/50HansD_20120322. pdf.

Pyles, L. (2008). Community organising for post disaster social development, locating social work. International Social Work, 50(3), 321-333.Doi:10.1177/0020872807076044.

Small, V. (2011, June 23). Crown to buy 5100 quake hit Christchurch homes. The Christchurch Press. Retrieved from http: / / www.stuff.co.nz / national/ christchurch-earthquake/5179959/ Crown-to-buy-5100-quake-hit-Christchurch-homes.

Soliman, H., \& Rogge, M. (2002). Ethical considerations in disaster services: A social work perspective. Electronic Journal of Social Work, 1(1), 1-23. Retrieved from http:/ / www.centerforurbanstudies.com/documents/electronic_library/disaster_planning/ethics_in_disasterplanning.pdf.

Stewart, A. (2012, April 16). Stressed out, irate residents on the rise. The Press, p. A4.

Tarrant, A. (2012). Govt comfortable with current intervention in Christchurch housing market, but always open to ideas, Housing Minister Heatly says. Retrieved May 9th 2012 from Interest.co.nz website: http: / / www.interest.co.nz / property / 58648 / govt-comfortable-current-interventions-christchurch-housing-market-always-open-ideas-.

Te Runanga o Ngai Tahu. (2011). He huanui ara ake mo Waitaha. Retrieved April 142012 from Ngai Tahu website http: / / www.ngaitahu.iwi.nz / Earthquake / RuWhenua/He-Huanui-Ara-Ake-mo-Waitaha-Te-Runanga-oNgai-Tahu-interim-input-on-the-draft-CERA-Recovery-Strategy.pdf.

The International Reference Centre for Psychosocial Support. (2009). Psychosocial Intervention (Handbook). Retrieved from: http: / / mhpss.net/wp-content/ uploads / group-documents / 22 / 1328075906-PsychosocialinterventionsAhandbookLowRes.pdf.

Waitangi Tribunal. (2012). Principles of the Treaty. Retrieved April 14th from the Waitangi Tribunal website: http: / / www.waitangi-tribunal.govt.nz/treaty/principles.asp. 